\title{
Study on Selected Physiological Parameters of Groundnut in Relation to Design of Groundnut Combine for Threshed Crop
}

\author{
Er. B. Vennela*, C. Ramana, M. V. Ramana, S. Joseph Reddy, \\ S. Kalleemullah and K. Lavanya Kumari \\ College of Agricultural Engineering, Bapatla, Andhra Pradesh, India \\ *Corresponding author
}

\begin{abstract}
Keywords
Physiological

Parameters,

Groundnut,

Threshed Crop

Article Info

Accepted:

25 October 2018

Available Online:

10 November 2018 ha-1 and about $70 \%$ of the world groundnut production occurs in the semi-arid tropics where the average yield is just around $800 \mathrm{~kg}$ ha- 1 . The study was conducted to relate the crop parameters with design of machine. Development of combine for threshed crop requires the data of plant height and weight of the plant in order to carry the crop and drop in the thresher. So, the present study was undertaken in order to design the machine. Selected crop parameters taken at 30,60,90 days after sowing and at the time of harvest like Plant Height, Width of Plant, Root Length, Number of pods, Number of unfilled pods and number of plants were measured in relation to design of machine. The minimum and maximum temperature requirements of groundnut are not well established but it germinates more quickly within range of $20-35^{\circ} \mathrm{C}$ with optimum temperature between 30$33^{\circ} \mathrm{C}$ for most rapid germination and seedling development. The results shown that the average Plant Height, Width of Plant, Root Length, Number of pods, Number of filled pods, Number of unfilled pods and number of plants are $35 \mathrm{~cm}, 17 \mathrm{~cm}, 25 \mathrm{~cm}, 22,15,7$ and 17 respectively were recorded at the time of harvest (100-120days of sowing). The pod weight increases in a linear fashion during pod filling and the linear growth rate continues until near harvest.
\end{abstract}

\section{A B S T R A C T}

India is the second largest producer of groundnuts in the world. The major growing state for groundnut is Gujarat, Andhra Pradesh, Tamil Nadu, Karnataka, Maharashtra Rajasthan, Madhya Pradesh, Orissa, and Uttar Pradesh. The world average yield is around $1300 \mathrm{~kg}$

\section{Introduction}

Groundnut or peanuts is a species in the legume or "bean" family. The peanut was probably first domesticated and cultivated in the valleys of Paraguay. It is an annual herbaceous plant growing 30 to $50 \mathrm{~cm}$ tall. Peanuts are known by many other local names such as earthnuts, ground nuts, goober peas, monkey nuts, pygmy nuts and pig nuts.
Despite its name and appearance, the peanut is not a nut, but rather a legume. India is the second largest producer of groundnuts in the world. Indian groundnuts are available in different varieties as bold or Runner, Java or Spanish and Red Natal. The major growing state for groundnut is Gujarat, Andhra Pradesh, Tamil Nadu, Karnataka, Maharashtra Rajasthan, Madhya Pradesh, Orissa, and Uttar Pradesh. the world average yield is around 
$1300 \mathrm{~kg}$ ha-1 and about $70 \%$ of the world groundnut production occurs in the semi-arid tropics where the average yield is just around $800 \mathrm{~kg}$ ha-1.The production of groundnut corresponds to the area under the crop. India has a cultivation history of growing groundnut around 250 years and now it is grown on an area of about 8 million hectare, producing about 8 million tonne $(\mathrm{mt})$ of pod and is the most important oilseed crop of the country.

Presently, India has the largest groundnut area (32\% of the world) and till 1992 was the chief-producer of groundnut in the world. But, from 1993 onwards, due to high productivity and better management practices China surpassed India and became the highest producer of groundnut. In India, the groundnut is grown in 260districts mostly as rainfed dry lands, crop on well drained sandy soils in low (750 $\mathrm{mm})$ and medium (750-1000 $\mathrm{mm}$ ) annual rainfall areas.

In order to develop a machine, study of the crop parameters in relation to machine was more important.

\section{Materials and Methods}

The present study is conducted at Madakasira, which is located in Ananthapur district of Andhra Pradesh. The Madakasira region is considered as one of the arid areas with low precipitation of $532 \mathrm{~mm}$. A field with sandy loam soils with gravel area was selected for the present study. Most of the madakasira region is characterized by sandy loam soils with gravel.

The study was conducted to correlate the crop parameters with design of machine. Development of combine for threshed crop requires the data of plant height and weight of the plant in order to carry the crop and drop in the thresher. So, the present study was undertaken in order to design the machine
Selected crop parameters taken at 30, 60, 90 days after sowing and at the time of harvest

\section{Plant Height}

The plant height of the crop was measured by randomly selecting one square meter area with the help of the measuring scale at 30, 60, 90 days after sowing and at the time of harvest as shown in Fig: 1

\section{Width of Plant}

The plant width of the crop was measured by randomly selecting one square meter area with the help of the measuring scale.

At 30, 60, 90 days after sowing and at the time of harvest.

\section{Number of plants and pods}

The number of plants and pods per square metre area of crop as shown in figure was counted by randomly uprooting the plants in the selected one square metre area at 30,60, 90 days after sowing and at the time of harvest.

\section{Number of unfilled pods}

The number of unfilled pods per square meter area of crop was measured by counting the pods with the hand by randomly uprooting the plants in the selected one square meter area 30, 60, 90 days after sowing and at the time of harvest.

\section{Root Length}

The root length of the crop was measured by randomly uprooting the plants in the selected one square meter area with the help of the measuring scale at 30, 60, 90 days after sowing and at the time of harvest. 
Fig.1 Recording of data at the field by using square meter

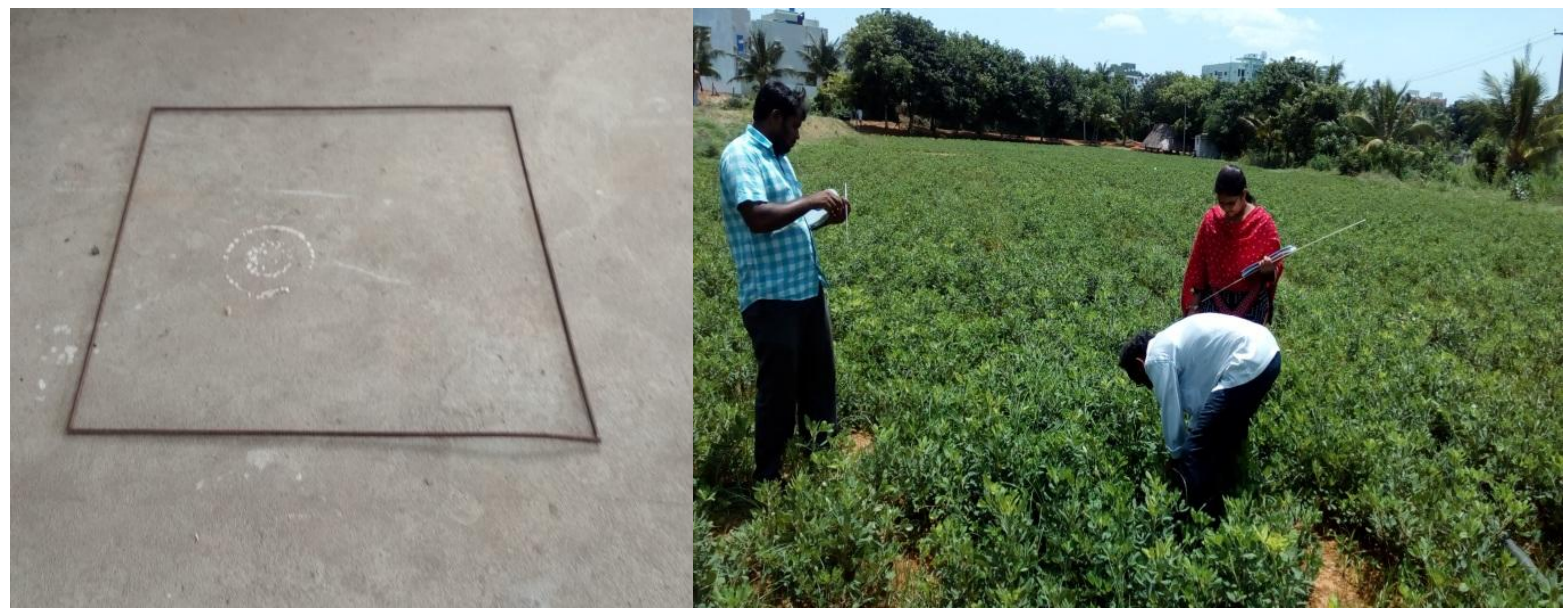

Fig.2 Number of pods

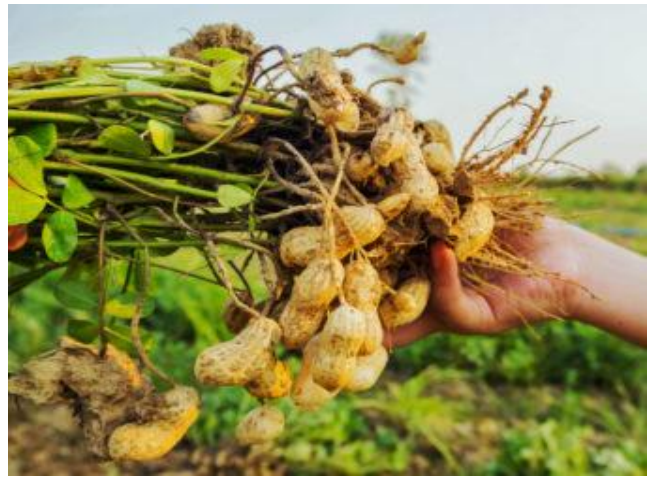

Table.1 Selected physiological parameters of groundnut at $13 \%$ moisture content

\begin{tabular}{|c|c|c|c|c|c|c|c|c|}
\hline $\begin{array}{l}\text { Number } \\
\text { of days }\end{array}$ & $\begin{array}{l}\text { Plant } \\
\text { height, } \\
\text { (cm) }\end{array}$ & $\begin{array}{l}\text { Plant } \\
\text { width, } \\
\text { (cm) }\end{array}$ & $\begin{array}{l}\text { Avg No. } \\
\text { of pods } \\
\text { per plant }\end{array}$ & $\begin{array}{l}\text { Avg No. of } \\
\text { filled } \\
\text { pods/plant }\end{array}$ & $\begin{array}{l}\text { Avg No. of un } \\
\text { filled } \\
\text { pods/plant }\end{array}$ & $\begin{array}{l}\text { Avg Plant } \\
\text { populatin/ } \\
\text { m2 }\end{array}$ & $\begin{array}{l}\text { Avg Pod } \\
\text { yield } / \mathrm{m} 2 \\
\text { (g) with } \\
\text { shell }\end{array}$ & $\begin{array}{l}\text { Avg } \\
\text { Root } \\
\text { length } \\
\text { (cm) }\end{array}$ \\
\hline 0-30 & 13 & 08 & $\begin{array}{l}\text { Flower } \\
\text { initiation }\end{array}$ & Nill & Nill & 32 & Nill & 09 \\
\hline $30-60$ & 21 & 11 & 13 & Nill & $\begin{array}{l}\text { Nill (pod grain } \\
\text { formation) }\end{array}$ & 28 & $\begin{array}{l}278 \\
\text { (partially } \\
\text { filled } \\
\text { pods) }\end{array}$ & 19 \\
\hline $60-90$ & 28 & 15 & 18 & 12 & 6 & 17 & 300 & 20 \\
\hline $\begin{array}{l}\text { At the } \\
\text { time of } \\
\text { harvest } \\
(100-120)\end{array}$ & 35 & 17 & 22 & 15 & 7 & 17 & 380 & 25 \\
\hline
\end{tabular}




\section{Results and Discussion}

In a 110-120 days crop, the flower initiation starts at 30DAS, and that of pod at 45 DAS. The pod achieves maximum number at 55 DAS and then filling starts and depending upon the duration, the crop matures in 110120 days. The pod fill is maximum at 80 DAS (A. L. Singh 2004). The minimum and maximum temperature requirements of groundnut are not well established but it germinates more quickly within range of 20$35^{\circ} \mathrm{C}$ with optimum temperature between 30 $33^{\circ} \mathrm{C}$ for most rapid germination and seedling development. In moist soil, the primary roots emerge in 24-36 $\mathrm{h}$ and root grows 0.5 to 4.0 $\mathrm{cm}$ in 4 days. Mohammed Ali et al., (1974) found the period of maximum growth between 56-97 days in bunch varieties. As in the table 1 the pod number and weight can be measured from at about 60days, pod number rises rapidly to a maximum at 100-120 DAS and then remains constant till harvest. The table. 1 shows the pod weight increases in a linear fashion during pod filling and the linear growth rate continues until near harvest. The parameters study revealed that the space for conveying the crop should be about $40-50 \mathrm{~cm}$ as the width of the single plant was $17 \mathrm{~cm}$.

\section{References}

Harrison Kwame Dapaah, Ibrahim Mohammed and Richard Tuyee Awuah. 2014. Growth and yield performance of groundnuts (arachis hypogaea L.) in response to plant density. International Journal of Plant \& Soil Science. 3(9): 1069-1082.

Jaime Cuauhtemoc Negrete. 2015. Current status and strategies for Harvest Mechanization of peanut in Mexico International Journal of Agriculture \& Environmental Science 2: 7-15

Keshavulu, K., Farzana Jabeen, Reddy, K.B., Rao, P.S., Reddy, B.M., Radhika, K. 2003. Morphological, chemical and electrophoretic descriptors of groundnut varieties. National Seed Project (Crops), IARI, New Delhi. Technical Bulletin No. 9, 1-72.

Md. Quamruzzaman, Md. Jafar Ullah, Md. Fazlul Karim, Nazrul Islam, Md. Jahedur Rahman, Md. Dulal Sarkar. 2017. Physiological Growth and Yield of Two Groundnut Varieties as Influenced by Light and Boron. Not Sci Biol,, 9(2): 280-286

Mohammed Ali, Mohan J S and Shanta R. 1974. Response of groundnut to different moisture regimes and farmyard manure. Madras Agricultural Journal 67: 472-476.

Oliveira, M.A.P. and Vails, J.F.M. 2003. Morphological characterization and reproductive aspects in genetic variability studies of forage peanut. Scientia Agricola. 60(2): 299-304.

Singh, L. 2004. Growth and physiology of Groundnut. Groundnut Research in India. pp 178-212.

\section{How to cite this article:}

Vennela Er. B., C. Ramana, M. V. Ramana, S. Joseph Reddy, S. Kalleemullah and Lavanya Kumari K. 2018. Study on Selected Physiological Parameters of Groundnut in Relation to Design of Groundnut Combine for Threshed Crop. Int.J.Curr.Microbiol.App.Sci. 7(11): 36083611. doi: https://doi.org/10.20546/ijcmas.2018.711.412 